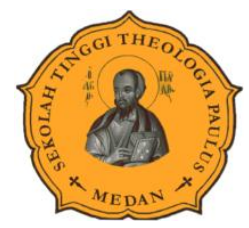

\title{
Menyikapi Perbedaan Pandangan Christology from Above and Christology from Below
}

Robert Pangaribuan

Sekolah Tinggi Theologia Paulus, Medan

robertpangaribuan@gmail.com

\begin{abstract}
The existence of Jesus in the world at the past time has raised many questions about who He really is. He has the power to carry out powerful and miraculous services that other ordinary human beings cannot possibly do. Pluralists and Liberals question the existence of Jesus; is he really the God who has descended from heaven and become human. To see the existence of the two, it is known the Christology from above and below. This article aims to criticize that theory. The method used is descriptive, using related variables to explain the ratio of both theories of Christology.
\end{abstract}

Keywords: Christian; culture; custom; tradition

\begin{abstract}
Abstrak: Kehadiran Yesus di dalam dunia pada masa lalu telah memunculkan banyak pertanyaan tentang siapakah Dia sesungguhnya. Ia berkuasa melakukan pelayanan yang penuh kuasa dan mujizat yang tidak mungkin dapat dilakukan oleh manusia biasa lainnya. Kaum Pluralis dan aliran Liberal mempersoalkan keberadaan Yesus; apakah Ia benar-benar Tuhan yang telah pernah turun dari surga dan menjadi manusia. Untuk melihat keberadaan yang dua itu dikenallah teori Kristologi atas dan bawah. Artikel ini bertujuan untuk mengkritisi teori tersebut. Metode yang digunakan adalah deskriptif, menggunakan iteratur yang terkait untuk menjelaskan nisbah kedua teori kristologi tersebut.
\end{abstract}

Kata kunci: adat istiadat; kebudayaan; Kristen

\section{PENDAHULUAN}

Sebelum kita memahami lebih jauh makna Krsitologi dari Atas (Christology From Above) dan Kristologi dari Bawah (Christology From Below) ada baiknya kita mengenal dulu definsi dan makna Kristologi dari beberapa sumber. Kristologi adalah cabang ilmu teologi yang membicarakan tentang posisi Yesus Kristus di dalam agama Kristen. ${ }^{1}$ Dalam hal ini Krsitologi adalah merupakan salah satu cabang ilmu teologi yang berbicara dan memaknai tentang hakekat dan keberadaan Yesus. Secara umum makna kehadiran Kristus bagi orang Kristen diyakini sebagai pemelihara dan penyelamat dunia terkait dengan setiap persoalan hidup.

Dalam Kamus Alkitab (A Dictionary of the Bible) mencatat bahwa; "Kristologi, Doktrin tentang pribadi Kristus. Studi tentang-Nya telah menjadi bagian penting pemikiran

\footnotetext{
${ }^{1}$ https://id.wikipedia.org/wiki/Kristologi
} 
rasional mengenai iman monoteistik Yahudi, ketika mereka menyembah Yesus Kristus sebagai Allah."2 Dalam perjalanannya makna tentang Krsitologi terus berkembang bahkan tidak sedikit terjadi pertentangan tentang pemahaman hakekat Yesus ditinjau dari aspek Krsitologi yang dilakukan oleh para pemikir-pemikir teologi sesuai zamannya masingmasing. Browning juga mencatat "Setelah perdebatan panjang dan kadang-kadang sengit dalam Konsili Chalcedon di Asia Kecil pada 451. Gereja memberi definisi final mengenai Kristologi yang menegaskan kepercayaan kepada Yesus sebagai Satu Pribadi dengan Dua Hakekat, yang dipersatukan tanpa dikacaukan." Konsili Chalcedon menetapkan bahwa Yesus adalah merupakan salah satu dari bagian Tritunggal Allah yaitu merupakan Pribadi kedua dari KeTritunggalan Allah yang harus diterima dalam iman oleh setiap umat yang percaya kepada-Nya.

Penyelidikan soal kehidupan Yesus yang disebut sebagai Kristologi memang mangalami sejarah yang panjang, sejak abad pertama, tetapi studi ini memuncak pada abad ke-19, terutama setelah bangkitnya metode "kritik Alkitab" yang menyangkut keabsahan atau otoritas Alkitab dimana diantaranya menyangkut tentang keabsahan Yesus, dan yang akhirnya terus berkembang. Oleh sebab itu John Macquarrie dalam bukunya menyebut Kristologi sebagai:"Kristologi adalah studi dengan subyek Yesus Kristus, pribadi dan pekerjaanNya, atau, dilihat dari sudut lain, siapa Ia sebenarnya dan apa yang dilakukanNya."4

\section{Permulaan Krsitologi Alkitab}

Sesungguhnya Studi Kristologi sudah ada semasa hidup Yesus sendiri, hal tersebut bisa dilihat dari pertanyaan-pertanyaan yang menyangkut tentang diri-Nya semasa hidup-Nya, "Siapakah gerangan orang ini"? Bahkan hingga saat ini perdebatan tentang keberadaan Yesus juga masih terus berlangsung, baik oleh pribadi-pribadi maupun kelompok yang tergabung dalam mazab atau aliran tertentu. Alkitab mencatat bahwa, ketika orang-orang yang berada di synagoge yaitu rumah ibadat orang Yahudi telah mendengar pengajaran Yesus, maka takjublah mereka dan bertanya: Dari manakah telah diperoleh-Nya hikmat itu dan kuasa untuk mengadakan mujizat-mujizat itu? Bukankah Ia ini anak tukang kayu? (Mat.13:54). Di satu sisi orang-orang Nazaret tidak bisa menerima apa yang telah dilakukan oleh Tuhan Yesus, karena mereka sangat mengenal Yesus berikut keluarga jasmaniah-Nya, di sisi lain mereka juga telah melihat fakta yang tidak dapat dipungkiri yaitu pengajaran-Nya yang penuh hikmat dan kuasa, serta mujizat-mujizat yang telah mereka dengar dan juga yang telah mereka lihat sendiri dengan mata kepala mereka.

Dalam hal ini mereka telah diperhadapkan dengan suatu rahasia yang terdapat dalam diri Yesus. Sebab Yesus yang telah dibesarkan di kota Nazaret, dan merupakan anak

\footnotetext{
${ }^{2}$ W.R.F. Browning, Kamus Alkitab: A Dictionary of the Bible (Jakarta: BPK Gunung Mulia, 2007),
}

${ }^{3}$ Ibid., 216

${ }^{4}$ http://sttip.com/modul, isu-isu kristologi kontemporer.pdf 
seorang tukang kayu yang bernama Yusuf, mengajar mereka seperti orang yang berkuasa, tidak seperti ahli-ahli Taurat mereka. Sejak itu terjadilah pertikaian diantara mereka yang melihat dan mendengar kepada-Nya. Banyak yang berkata Ia kerasukan setan dan gila. Ada pula yang mengatakan itu bukan: Itu bukan perkataan orang yang kerasukan setan (Yoh.10: 19-21). Kepada murid-murid-Nya ia juga bertanya "Kata orang siapakah Aku ini?" (Mark. 8:27). Dengan pertanyaan ini Ia menunjukkan bahwa pada masa itupun sudah ada keragu-raguan mengenai siapakah Yesus itu, ada yang mengira Ia sebagai Yohanes Pembaptis, Elia atau seperti seorang nabi lainnya (Mar.8:28).

Sepanjang segala abad timbullah diantara manusia pertanyaan yang tidak pernah terjawab secara memuaskan sama sekali, yakni: sipakah gerangan Yesus ini? Sehingga dikalangan ahli-ahli teologia telah berkembang pemahaman tentang Yesus sesuai dengan perkembangan serta penelitian melalui studi-studi yang mereka lakukan. Pendapat para pakar saling bertentangan satu dengan yang lainnya, dengan mengajukan argumenargumen tertentu sebagai hasil survey atau penelitian yang mereka lakukan. Itu sebabnya dikalangan para ahli teologia pada saat ini ada dua kutub pandangan Kristologi yang saling bertentangan yaitu pandangan Kristologi dari Atas dan pandangan Kristologi dari Bawah (Christology from Above and Christology from Below).

Dengan demikian pandangan Kristologi adalah studi yang berpusat pada pertanyaanpertanyaan siapakah Yesus itu sesungguhnya, dari mana asalnya, dari mana Ia peroleh kemampuan supranatural-Nya sehingga Ia dapat melakukan mujizat-mujizat yang tidak mungkin bisa dilakukan oleh manusia biasa. Apa misi yang dibawa-Nya ke dunia ini untuk manusia dan latar belakang kedatangan-Nya. Donald Guthrie mengatakan bahwa, "Pembahasan di dalam bagian ini bertujuan untuk menjawabnya dengan meneliti ajaranajaran yang terdapat dalam PB tentang 'Siapakah sebenarnya Yesus Kristus'. Penelitian tentang siapakah Yesus mempunyai istilah yang khusus dalam bahasa teologi Kristen, yaitu kristologi."5

Pemahaman Kristologi dalam dua kutub yang berbeda yaitu Christology from above dan Christology from below adalah didasarkan dua persepsi yang berbeda, yaitu ada yang memandang tentang keberadaan Tuhan Yesus secara iman dan bersifat supranatural namun ada yang memandang tentang keberadaan Tuhan Yesus secara analisis empiris serta studi kritik Alkitab yang menggunakan akal budi semata. Sehingga hal-hal yang bersifat supranatural ditolak karena tidak dapat dibuktikan dengan studi analisis tertentu.

\section{Pengakuan Dari Perjanjian Baru}

Niftrik mengatakan bahwa, "Perjanjian Baru memberi kesaksian bahwa Allah telah mendatangi manusia dalam kedatangan Yesus Kristus, dan sebaliknya di dalam manusia Yesus orang Nazaret itu kita berjumpa dengan Allah sendiri." ${ }^{\prime 6}$ Kedatangan Yesus ke dunia ini tentu saja sesuai dengan rencana Allah untuk menyelamatkan umat-Nya yang berdosa

${ }^{5}$ Donald Guthrie, Teologi Perjanjian Baru 1 (Jakarta: BPK Gunung Mulia, 2015), 243

${ }^{6}$ GC. Van Niftrik \& BJ. Boland, Dogmatika Masa Kini (Jakarta: BPK Gunung Mulia, 2008), 187 
agar terbebas dari hukuman Allah yang kekal. Dengan kedatangan Tuhan Yesus ke dunia ini sebagai Anak yang diutus Allah untuk melakukan misi penyelamatan, sehingga setiap orang yang percaya kepada-Nya tidak binasa melainkan beroleh hidup yang kekal (Yoh.3: 16). Demikian juga halnya disebutkan bahwa murid-murid-Nya telah melihat Allah Bapa ketika melihat Yesus, meskipun Alkitab mencatat bahwa Yesus berasal dari Nasaret yang dibesarkan oleh Yusuf yang mempunyai profesi sebagai tukang kayu.

Niftrik menambahkan bahwa, Kebenaran itu seakan-akan disampaikan kepada kita melalui suatu garis "dari bawah ke atas", dan melalui suatu garis "dari atas ke bawah". Hal ini salah satu penyebab terjadinya pemahaman tentang Kristologi dari Atas dan Kristologi dari bawah. Pemahaman "dari bawa ke atas" terutama didapati dari kitab-kitab Injil synoptis seperti injil Matius, Markus dan Lukas. Para ketiga Penulis Injil ini seakanakan memulai dengan menceritakan tentang Yesus orang Nazaret yaitu menceritakan tentang perkataan-perkataan-Nya serta segala perbuatan-perbuatan yang telah dilakukanNya. Dengan demikian beberapa ahli teologi berbicara tentang Yesus yang dimulai dari Yesus berasal dari Nasaret. Kemanusiaan Yesus dilihat dari bawah yaitu sebagaimana manusia yang besar bersama-sama dengan manusia lainnya. Karena dalam Alkitab mencatat Yesus mempunyai ayah dan ibu dan juga saudara-saudara-Nya yang lahir dari hubungan antara sesama manusia. Tetapi demikian sebaliknya, Injil Yohanes seolah-olah berbicara "dari atas ke bawah", 'from above to below' sebagaimana diungkapkannya dalam Yohanes pasal 1. Namun hal ini akan diuraikan secara lebih mendalam dalam tulisan-tulisan berikut di bawah ini.

\section{METODE}

Metode yang digunakan dalam artikel ini adalah deskriptif historis serta analisis biblikal. Metode deskriptif digunakan untuk mendeskripsikan pandangan teori tentang Kristologi dari atas dan Kristologi dari bawah. Beberapa hal penting berkaitan dengan variabel pun dijelaskan dalam bagian ini.

\section{Kristus Iman dan Yesus Sejarah}

Timbulnya dikotomi kedua istilah tersebut adalah didasarkan adanya beberapa kaum teolog yang beraliran liberal untuk melakukan penyelidikan tentang Yesus yang berdasarkan sejarah. Itu sebabnya ada dua bentuk pandangan tentang keberadaan Yesus yaitu tentang. Berkaitan dengan hal tersebut maka munculah persoalan mengenai relasi peristiwa Yesus dan waktu penulisan Injil-injil. Dalam hal ini muncullah pertanyaan baru, yaitu: "dapatkah suatu pengertian yang pantas mengenai Kristus didasarkan atas data sejarah atau-kah itu harus disikapi dengan iman?

Kelompok Liberal mencoba menjawab pertanyaan ini melalui penelitian Yesus Sejarah (The Quest of The Historical Jesus)." ${ }^{8}$ Mereka melakukan penelitian Yesus

\footnotetext{
${ }^{7}$ Ibid.

${ }^{8}$ Stevri Indra Lumintang, Theologi Abu-Abu Pluralisme Agama (Gandum Mas: 2009), 181
} 
Sejarah tersebut melalui metode penelitian kritik Bentuk dan kritik Redaksi. Namun demikian pada kenyataannya penelitian Yesus Sejarah ini ditentang oleh teolog-teolog Neo-Ortodoks. ${ }^{9}$ Meskipun sudah ditentang oleh beberapa tokoh teologia, namun penelitian mengenai Yesus Sejarah belumlah berhenti, hal ini dibuktikan dengan adanya penyelidikan baru atau yang disebut dengan The New Quest dan The Jesus Seminar. Bersamaan dengan hal tersebut muncul lagi penyelidikan yang ketiga mengenai Yesus Sejarah (The Third Quest of The Historical Jesus).

Tindakan Penyelidikan Yesus Sejarah (The Quest of The Historical Jesus), Kaum Liberal telah memperkarsai penyelidikan mengenai Yesus Sejarah dengan mengunggulkan metode kritik Alkitab. Menurut Erickson bahwa orientasi penelitian ini ialah:

Untuk menemukan seperti apakah Yesus yang sesungguhnya dan apakah memang Ia datang, 'dikenal sebagai penyelidikan Yesus Sejarah'. Yang mendasari penyelidikan ini adalah pengharapan bahwa Yesus yang sesungguhnya akan terbukti berbeda dengan Kristus yang tampak dalam Kitab Suci, dan yang dalam beberapa pengertian sebagai hasil dari proses teologi Paulus dan penulis yang lain. ${ }^{10}$

Sehubungan dengan hal tersebut ada empat tokoh teologia yang dikenal memulai penelitian mengenai Yesus Sejarah yaitu: David Straus (1807-1874) dengan bukunya " $A$ New Life of Jesus"; Ernest Renan. Keduanya memandang Yesus sebagai manusia biasa yang baik, sebagai seorang guru yang memiliki kebenaran-kebenaran rohani, karenanya mereka menolak Ke-Allahan Yesus. Adolf Von Harnack (1851-1930) dengan bukunya yang terkenal "What is Christianity?" Ia berpendapat bahwa: "Injil-injil tidak memberikan kepada kita arti mengenai susunan biografi Yesus, karena mereka menceritakan kepada kita sangat sedikit mengenai awal kehidupan Yesus. Albert Schweitzer (1875-1965), dengan bukunya yang berjudul "Quest of The Historical Jesus". Ia membangun asumsinya dengan menyatakan bahwa: "Injil-injil adalah tidak dapat dipercaya dan bahwa Yesus Sejarah adalah seorang yang biasa, sebagai dongeng yang telah mengalami perkembangan. $^{11}$

Para penyelidik Yesus Sejarah melihat Yesus hanya sebagai manusia biasa saja yang rohani dan bermoral serta memiliki kebenaran-kebenaran rohani. Penekanan mereka yaitu berorientasi pada humanitas, pengalaman agamawi dan metode penelitian ilmiah. Namun pemikiran dan pendapat mereka dilawan oleh beberapa tokoh teologi lain seperti Barth, Bultman dan Bruner yang beraliran Neo-Ortodoks. Mereka adalah orang-orang yang anti teologi Liberal, sekalipun pada hakekatnya, konsep mereka adalah Liberal.

Dengan adanya argumentasi yang telah dilakukan oleh Barth, Bultman yang menekankan transendensi dan kekuasaan Allah serta kebutuhan manusia akan penebusan, telah menggagalkan kelompok liberal yang telah membuang unsur-unsur supernatural dalam kekristenan. Keraguan Bultman terhadap Yesus Sejarah yang telah dimunculkan

\footnotetext{
${ }^{9}$ Ibid.

${ }^{10}$ Millard J. Erickson, Christian Theology, 663,

${ }^{11}$ Lumintang, Theologi Abu-Abu Pluralisme Agama, 182
} 
kaum Liberal menimbulkan reaksi dari pengikut-pengikutnya yang terdekat. Sehingga pada tahun 1952, penyelidikan mengenai Yesus Sejarah kembali menjadi pokok pembicaraan yang hangat setelah seorang murid Bultman yang bernama Ernst Kasmann mengadakan suatu ceramah tentang penelitian PB yang mengetengahkan kembali Yesus yang berisifat Historis, yaitu apa yang terjadi pada Yesus yang dibuat oleh kepercayaan orang-orang Kristen mula-mula. Jadi Yesus yang Historis itu adalah Yesus yang diberitakan (kerygma). ${ }^{12}$ Dengan demikian perdebatan tentang pandangan Yesus Sejarah bahkan masih berlangsung hingga saat ini, dengan adanya kelompok-kelompok yang berorientasi pada aliran tertentu, dan pandangan ini adalah salah satu sumber munculnya Kristologi "dari bawah ke atas."

\section{Metode Krsitologi dari Atas (The Christology From Above)}

Sebagai konsekuensi dari penyelidikan Yesus Sejarah (The Quest of The Historical Jesus) sebagaimana telah diuraikan di atas maka muncullah dua titik berangkat ber-Kristologi yaitu munculnya dua metode pendekatan. Kedua metode pendekatan itu adailah Kristologi dari Atas (The Christology from Above) dan dan Kristologi dari Bawah (Christology from Below).

Kristologi dari atas adalah dikenal "sebagai strategi dasar dan orientasi dari kristologi gereja abad permulaan."13 Stevri menambahkan bahwa Kristologi gereja mula-mula ialah kristologi ortodoks, kristologi Chalcedon dimana tidak ada pemisahan antara iman dan sejarah, antara Alkitab dan sejarah. ${ }^{14}$ Dalam hal ini pulalah adanya kristologi yang murni sebelum adanya penyelidikan Yesus Sejarah. Metode ini mulai dengan Anak Allah yang ilahi, kemudian muncul pertanyaan bagaimana dan dengan cara bagaimana Ia menjadi manusia. Metode ini sejak abad ke XX telah dipakai Karl Bath, Rudolf Bultmann dan Emil Bruner, sebagai reaksi terhadap Metode Kristologi from below dari teolog Liberal dengan "the quest of the historical Jesus."

Kristologi yang murni yang sudah ada sebelum adanya penyelidikan Yesus Sejarah adalah merupakan pandangan gereja mula-mula yaitu bahwa Krsitologi dimulai dari atas. Hal ini dimulai dengan pandangan tentang ke-Allahan dan Kemanusiaan Yesus seperti yang terdapat di dalam Injil Yohanes pasal 1. Niftrik menulis bahwa "Injil Yohanes seolaholah mulai "dari atas ke bawah": apabila kita mau berjumpa dengan Allah, maka haruslah kita memandang kepada manusia Yesus orang Nazaret ini; percaya kepada Allah, percaya kepada Allah berarti menyambut Yesus ini, sebab ... Allah telah menjadi manusia dalam munculnya Yesus Kristus (Yoh.1:14). ${ }^{15}$ Dalam injil Yohanes Pasal 1 ayat 1-3 sangat jelas menggambarkan tentang Kristologi yang berorientasi pada pandangan "dari atas ke bawah". Stephen Tong menulis dalam bukunya Allah Tritunggal bahwa: "Injil Yohanes

\footnotetext{
${ }^{12}$ Ibid. 183

${ }^{13}$ Erickson, Christian Theology, 665

${ }^{14}$ Lumintang, Theologi Abu-Abu Pluralisme Agama ,190

${ }^{15}$ Niftrik \& Boland, Dogmatika Masa Kini, 187
} 
dimulai dengan ayat-ayat Kristologi yang penting di dalam seluruh Alkitab. ${ }^{16}$ Meskipun ayat tersebut sangat singkat namun dapat memiliki makna yang sangat luas yang menggambarkan tentang Ketuhanan Yesus dan sekaligus Kemanusiaan Yesus.

Kutipan berikut menjelaskan lagi bahwa "Pada mulanya adalah Firman; Firman itu bersama-sama dengan Allah dan Firman itu adalah Allah." "Pada mulanya .."(Yunani: en arche...) disini bukan berarti permulaan dari waktu, bukan permulaan ciptaan, melainkan permulaan yang melampaui waktu dan ciptaan, yaitu permulaan di dalam kekalan." ${ }^{\prime 17}$ Jadi sangat jelas dipahami bahwa arti permulaan itu merupakan sesuatu yang sudah ada sejak semulanya sebelum segala sesuatu itu ada sebagai tindakan Allah dalam proses penciptaan. Stephen Tong menambahkan: "Mengapa demikian?, karena karya ciptaan, baru disebutkan di dalam ayat 3. Maka Allah yang menjadi permulaan yang melampaui waktu, tempat, serta segala sesuatu yang diciptakan-Nya. Jadi, "Pada mulanya..." menunjuk pada permulaan ciptaan."18 Dengan demikian segala sesuatu sebelum dunia ada, maka jelaslah bahwa segala sesuatu pada mulanya dari atas, diciptakan dari atas dan datangnya dari atas. Allah adalah Firman, Firman itu adalah Allah, Firman itu berada di atas dan turun menjadi daging kedalam dunia melalui kehadiran Tuhan Yesus yang telah menjadi manusia (Yoh.1:14).

Yesus datang ke dunia ini sebagai Anak Manusia dan juga disebut sebagai Anak Allah yang datang untuk melakukan misi penyelamatan manusia yang berdosa. John Drane menyebutkan bahwa, "Ada yang berpendapat, kalau Yesus berbicara mengenai diri-Nya sendiri sebagai 'Anak Manusia', Ia hanya ingin menekankan bahwa sebagian tabiat-Nya bersifat manusiawi dan biasa, sedangkan bagian lain dari tabiat-Nya itu dapat dilukiskan dengan istilah "Anak Allah'."19 Itu sebabnya hakekat keberadaan Tuhan Yesus dinyatakan sebagai 100\% Tuhan dan 100\% manusia. Disatu sisi Yesus sebagai manusia yang telah datang ke dunia, disisi lain Ia adalah Tuhan yang dinyatakan sebagai Anak Allah.

Lumintng menuliskan, ada tiga kunci untuk mengerti Kristologi dari atas, menurut Erickson yang diperolehnya dari tulisan Emil Brunner, yaitu: Dasar pengertian tentang Kristus bukanlah Yesus Sejarah, melainkan kerygma, proklamsi gereja berkenaan dengan Kristus. Dalam penyusunan suatu Kristologi, ada suatu referensi bagi tulisan-tulisan Paulus dan Injil keempat. Yang terlebih dahulu berisi penafsiran teologis yang lebih eksplisit, sedangkan Injil-Injil secara mendasar adalah laporan yang memuat fakta tentang perbuatan dan pengajaran Yesus. Iman kepada Kristus bukanlah didasarkan pada bukti rasional atau legitimasi. Iman tersebut tidak dibuktikan secara ilmu pengetahuan. Isi iman diletakkan di luar wilayah akal budi manusia dan penelitian historis dan tidak dapat dibuktikan secara

\footnotetext{
${ }^{16}$ Stephen Tong, Allah Tritunggal (Surabaya: Momentum, 2013), 62

${ }^{17}$ Ibid., 62-63

${ }^{18}$ Ibid., 63

${ }^{19}$ John Drane, Pemahaman Perjanjian Baru (Jakarta: BPK Gunung Mulia, 2006), 74
} 
konklusif. Sedangkan penelitian Historis berusaha menyingkirkan hambatan-hamabatan kepercayaan yang berbeda, itu tidak dapat membangun kepercayaan mereka. ${ }^{20}$

Berdasarkan hal tersebut diatas jelaslah bahwa dasar pemahaman Kristologi dari atas ke bawah sudah sangat jelas yaitu pada mulanya segala sesuatunya dari atas sebelum segala sesuatunya ada termasuk segala yang berada di bawah bumi. Berbicara tentang keAllah-an, Louis Berkhof menulis dalam bukunya "tetapi sungguh ada suatu Pribadi yang keberadaan dan kesadaran-Nya bersumber pada diri-Nya sendiri, suatu Keberadaan berpribadi yang merupakan asal mula dari segala sesuatu, yang jauh melampaui segala mahluk ciptaan, akan tetapi pada saat yang sama hadir terlibat dalam segala bagian dari ciptaan-Nya itu." ${ }^{, 1}$ Keberadaan Allah bersumber dari diri-Nya sendiri dan tidak ada proses penciptaan akan diri Allah, Ia menciptakan segala sesuatu dari yang tidak ada menjadi ada, termasuk manusia, bahkan Ia sendiri terlibat dalam segala akan ciptaan-Nya hingga saat ini. Allah yang pada awalnya adalah Firman yang menciptakan segala sesuatu lewat Firman-Nya, telah mendatangi manusia di dalam diri Yesus yaitu Firman yang telah menjadi manusia (Yoh.1:14). Hal tersebut dimaksudkan untuk melakukan misi penyelamatan akan manusia yang berdosa, melalui kematian dan kebangkitan-Nya sebagai jalan penebusan dari kuasa maut untuk mendapat bagian dalam keselamatan hidup yang kekal.

\section{Metode Krsitologi dari Bawah (The Christology From Below)}

Pemahaman "Kristologi dari atas" mendapat tanggapan dari beberapa tokoh teologi lainnya. Metode tersebut diejek sebagai metode fideistik (berdasarkan iman) dan spekulatif (tidak sesuai dengan pemikiran modern). Salah satu tokoh yang sangat terkenal menolak "Kristologi dari atas" adalah Wolfhart Pannenberg dengan bukunya "Jesus God Man." dengan mengajukan beberapa argumen-argumen tertentu. Ada tiga alasan, ia tidak memakai Kristologi dari atas yaitu: Tugas kristologi adalah untuk menyajikan laporan rasional mengenai kepercayaan kepada ke-Allahan Yesus, hal itu diperdebatkan pada masa kini. Kristologi dari atas adalah tidak dapat diterima karena ia mengusulkan mengenai ke Allahan Yesus. Kristologi dari atas cenderung mengabaikan arti sejarah Yesus dari Nazaret yang berbeda. Dengan tegas mengatakan, kristologi dari atas mungkin hanya dari posisi Allah sendiri, dan bukan untuk kita. ${ }^{22}$

Pemikiran-pemikiran tersebut sebagaimana telah diuraikan di atas adalah merupakan gagasan-gagasan yang telah disampaikan oleh para teolog yang beraliran liberal. Mereka sangat mengutamakan logika berpikir yang tidak dapat menerima sesuatu yang bersifat supranatural yang hanya bisa diterima melalui iman. Atas dasar inilah ia mencetuskan metode kristologi dari bawah (The Christology From Below) yang meletakkan pandangannya dimulai dari manusia Yesus dari Nazaret, kemudian bertanya bagaimana

\footnotetext{
${ }^{20}$ Lumintang, Theologi Abu-Abu Pluralisme Agama, 191

${ }^{21}$ Louis Berkhof, Teologi Sistematika (Surabaya: Momentum Christian Literature, 2007), 10

${ }^{22}$ Lumintang, Theologi Abu-Abu Pluralisme Agama, 191
} 
caranya Ia menjadi Allah. Pannenberg memulai dari Yesus yang historis untuk kemudian tiba pada ke Allahan-Nya.

Niftrik dalam bukunya menulis bahwa "Dalam menunjuk kepada manusia Yesus orang Nazaret itu, mereka mengaku dan mengajak untuk mengaku: Yesus orang Nazaret, anak Yusuf dan Maria itu, Dialah Mesias (Kristus) yang telah dijanjikan oleh Allah dan kini diberikan kepada kita, bahkan di dalam manusia ini kita berjumpa dengan Allah sendiri (garis "dari bawah ke atas"). ${ }^{23}$

Memang Kemanusiaan Yesus tidak hanya digambarkan sebagai Anak yang sama sekali bergantung kepada Bapa. Ia juga dilukiskan dalam terminologi manusia seutuhnya. Ia digambarkan sebagai manusia biasa yang menikmati hubungan kekeluargaan yang biasa. ${ }^{24}$ Sebagai manusia, Yesus pernah menghadiri pesta pernikahan di Kana bersama ibunya, Ia pernah mengalami kehausan dan kelelahan sebagaimana manusia biasa, Ia pernah sedih, kecewa, marah, lahir dari rahim Maria dan bertumbuh menjadi manusia dewasa dan lain sebaginya. Namun hal tersebut tidak bisa melihat Yesus hanya dari keberadaan Yesus dari Nazaret yang menyebabkan keilahian Yesus diabaikan. Alkitab mencatat bahwa Yesus selaku manusia telah banyak melakukan mujizat yang bersifat supranatural yang tidak bisa dilakukan oleh manusia biasa. Namun oleh karena para teolog yang beraliran liberal yang hanya mengedepankan logika berpikir yang harus bisa dibuktikan dengan suatu fakta-fakta melalui penelitian tertentu, maka muncullah gagasan "Kristologi dari bawah."

Para teolog beraliran liberal ini, benar-benar mengabaikan kesaksian keseluruhan Alkitab baik dari kitab Perjanjian Lama yang telah banyak menubuatkan tentang rencana kehadiran Yesus ke dunia dan juga kesaksian Perjanjian Baru yang telah menggenapi segala nubuat dalam Perjanjian Lama tentang Yesus.Memang para aliran liberal tersebut tidak sepenuhnya menolak ke Tuhanan Yesus, karena mereka memandang kemanusiaan Yesus dari sudut historis yaitu Yesus berasal dari Nazaret (from below), baru kemudian dilihat sifat ke Allahan-Nya (From above). Dengan memiliki pandangan yang demikian, maka mereka seakan-akan mengajukan pemikiran bahwa Yesus berasal dari manusia menjadi Allah, yaitu manusia memiliki sifat-sifat ke Ilahian. Hal ini sangat bertolak belakang dengan kesaksian Alkitab yang menyatakan Allah telah menjadi manusia untuk melakukan misi penyelamatan. Dengan demikian para teolog yang beraliran liberal ini, tidak menerima dan tidak mempercayai Alkitab sebagai Firman Allah sepenuhnya, sehingga mereka tidak akan pernah mengerti tentang kebenaran Firman Allah yang telah ditulis dalam Alkitab, karena mata rohani mereka telah dibutakan.

Cara pandang mereka sama seperti orang-orang Yahudi yang telah ditegur oleh Musa, ketika Musa berkata: "Sudah kamu lihat segala yang dilakukan TUHAN di tanah Mesir di depan matamu terhadap Firaun dan terhadap semua pegawainya dan terhadap

\footnotetext{
${ }^{23}$ Niftrik \& Boland, Dogmatika Masa Kini, 187

${ }^{24}$ George Eldon Ladd, Teologi Perjanjian Baru Jilid 1 (Bandung: Kalam Kudus, 2010), 335
} 
seluruh negerinya: cobaan-cobaan yang besar yang telah dilihat oleh matamu sendiri, tanda-tanda dan mukjizat-mukjizat yang besar itu. Tetapi sampai sekarang ini TUHAN tidak memberi kamu akal budi untuk mengerti atau mata untuk melihat atau telinga untuk mendengar" (Ulangan 29:2-4)." 25 Dengan demikian setiap orang yang tidak percaya dan tidak menaruh iman terhadap Firman Allah sepenuhnya maka mereka tidak diberi akal budi untuk memahami Firman Tuhan, mereka tidak bisa melihat dan tidak bisa mendengar dalam arti rohani. Seakan-akan mereka telah buta untuk melihat terang Firman Tuhan yang sesungguhnya.

\section{PEMBAHASAN}

\section{Apa Kata Alkitab Mengenai Keilahian Yesus}

Sesungguhnya keberadaan Allah tidak perlu dibuktikan dengan cara bentuk apapun, sebab manusia tidak dapat menjangkau keberadaan Allah yang penuh misteri yang melampaui segala akal pikiran manusia.Kuyper dalam kutipan buku Loies Berkhof menjelaskan bahwa "Usaha untuk membuktikan keberadaan Allah tidak berguna, dan tidak akan berhasil. Usaha tersebut tak berguna apabila si pencari percaya bahwa Allah adalah pemberi pahala kepada mereka yang mencari Dia." ${ }^{26}$ Dalam hal ini dapat dipahami, adalah suatu pekerjaan yang sia-sia jika seseorang mencoba untuk mencari kebenaran tentang hakekat Allah yang berorientasi pada akal dan pikiran manusia semata dengan melakukan banyak metodologi penelitian. Bahkan hal tersebut juga merupakan hal yang tidak berguna bagi orang tersebut dan tidak akan pernah berhasil. Berkhof menambahkan, "Usaha itupun tidak akan berhasil apabila usaha ini adalah suatu upaya untuk memaksa seseorang yang tidak mempunyai iman melalui cara-cara argumentasi sampai tiba kepada suatu pengakuan dalam arti logis.",27

Keberadaan Allah hanya dapat dibuktikan melalui pernyataan Allah melalui FirmanNya yang telah dikanonisasi dalam Alkitab yang dipercayai dan diimani oleh orang-orang Kristen. Keberadaan Allah hanya dapat diterima melalui iman, meskipun demikian iman itu bukanlah bersifat buta yang tidak memiliki dasar argumentasi sama sekali. Bukti keberadaan Allah telah dinyatakan pada Alkitab sebagai Firman Allah yang telah diilhamkan Allah melalui Roh Kudus yang ditulis oleh para nabi dan Rasul (2 Tim.3: 16).

Alkitab mencatat banyak bukti yang menyatakan tentang ke Allahan Yesus, selain kitab Injil Yohanes pasal 1 yang telah diuraikan di atas. Memang Yesus tidak pernah menyatakan secara langsung melalui ucapan-Nya bahwa Ia adalah Allah, namun melalui kesaksian, ucapan dan pernyataan orang-orang lain serta perbuatan Yesus sendiri dengan melakukan banyak mujizat yang melengkapi pelayanan-Nya, telah menunjukkan bahwa Yesus adalah Allah.

\footnotetext{
${ }^{25}$ Dave Hagelberg, Tafsiran Injil Yohanes Dari Bahasa Yunani (Yogyakarta: ANDI Offset, 2009), 213

${ }^{26}$ Berkhof, Teologi Sistematika ,11

${ }^{27}$ Ibid.
} 
Samin H. Sihotang dalam bukunya "Siapakah Nama Sang Pencipta?" menyebutkan bahwa "Sebenarnya, pada awal penampakan-Nya kepada umum ketika Ia datang ke Sungai Yordan dimana Yohanes sedang membaptis, ada dua kesaksian penting di sana yang menunjukkan bahwa Ia adalah Allah Yang Menjelma atau barangkali lebih baik disebut bagian dari Allah Tritunggal." 28 Pada umumnya kesaksian orang lain yang mengungkapkan keberadaan apa yang ada pada diri kita khususnya perihal sesuatu kelebihan atau keunikan, akan lebih dapat diterima dibandingkan jika kita mengungkapkan sendiri yang cendrung bersifat subjektif. Demikian juga halnya tentang dua kesaksian yang diberikan tentang keberadaan Yesus yang disaksikan dalam Alkitab. Samin menambahkan, "Pertama kesaksian Yohanes sendiri (Mrk.1:7,8, Yoh.1:26-34). Dalam hal ini Yohanes bisa bersaksi karena sebelumnya, Roh Allah telah memberitahukan kepadanya siapa Dia (Yoh.1:32-34).

Kesaksian kedua adalah suara dari surga (Mrk.1:11)."29 Dalam hal ini kesaksian tersebut berasal dari Yohanes sendiri dan juga berasal dari Allah Bapa yang dinyatakanNya pada saat Yesus baru saja selesai dibaptis oleh Yohanes. Meskipun Yohanes Pembaptis mengungkapkan kesaksiannya, siapa Yesus sesungguhnya, namun kesaksian yang dia sampaikan tentang ke Allahan Yesus adalah juga berasal dari Allah Bapa. Hal ini dapat dilihat pada Yohanes 1: 33 ketika Yohanes Pembaptis mengatakan "Dia yang mengutus aku untuk membaptis dengan air, telah berfirman kepadaku: Jikalau engkau melihat Roh itu turun ke atas seseorang dan tinggal di atas-Nya, Dialah itu yang akan membaptis dengan Roh Kudus." Yohanes Pembaptis menegaskan kembali pada ayat 34 "Dan aku telah melihat-Nya dan memberi kesaksian: Ia inilah Anak Allah". Kesaksian yang kedua adalah pernyataan Allah secara langsung kepada Tuhan Yesus, ketika baru saja Ia dibaptis di sungai Yordan oleh Yohanes Pembaptis. Pada saat Ia keluar dari air, Ia melihat langit terkoyak, dan Roh seperti burung merpati turun ke atas-Nya. Lalu terdengarlah suara dari sorga: "Engkaulah Anak-Ku yang Kukasihi, kepada-Mulah Aku berkenan (Mrk. 1: 10-11).

William W.Menzies mengungkapkan dalam bukunya Doktrin Alkitab, yang menjelaskan Keilahian Tuhan Yesus Kristus berdasarkan injil Yohanes 1:18 "Bahwa Ia berada di pangkuan Bapa, tidak mengungkapkan perbedaan dalam hakikat atau sifat yang rendah, melainkan menunjukkan hubungan yang akrab dengan Bapa dan keikut sertaan dalam otoritas Bapa. ${ }^{, 30}$ Dari kutipan tersebut jelas tidak ada perbedaan tingkat kederajatan Allah dalam diri Yesus dengan ke-Allah-an Bapa di sorga. Meskipun Yesus disebut sebagai Anak Allah yang dalam Ketritunggalan sebagai Pribadi kedua, bukanlah berarti sebagai hubungan antara anak dan ayah dalam hubungan biologis, tetapi merupakan hubungan kesetaraan ke-Allah-an yang mengambil wujud dalam peran masing-masing. Dalam hal ini Yesus telah mengungkapkan kesetaraan-Nya dengan Allah Bapa di sorga ketika Ia berkata "Barang siapa telah melihat Aku, Ia telah melihat Bapa (Yoh.14: 9).

\footnotetext{
${ }^{28}$ Samin H.Sitohang, Siapakah Nama Sang Pencipta? (Bandung: Kalam Kudus, 2003), 54

${ }^{29}$ Ibid.

${ }^{30}$ W.Menzies \& Stanley M.Horton, Doktrin Alkitab (Malang: Gandum Mas, 2003), 61
} 
Yesus menegaskan kembali bahwa Ia ada di dalam Bapa dan Bapa ada di dalam Dia (Yoh.14: 10). Sesungguhnya dalam hal ini antara Yesus sebagai Anak telah terjadi kemanunggalan dengan Allah Bapa yang tidak bisa dipisahkan dengan alasan dan argumen apapun, sebab sesungguhnya mereka adalah satu. Menzies menambahkan "Yesus Kristus bukan hanya sepenuhnya Allah, Ia juga sepenuhnya manusia. Ia bukan sebagian Allah dan sebagian manusia. Dahulu dan sekarang Ia adalah $100 \%$ Allah dan pada waktu yang sama 100\% manusia." 31 Dengan demikian Yesus sebagai manusia memiliki dua kodrat yaitu kodrat kemanusiaan yang secara lahiriah sama dengan yang dimiliki oleh manusia biasa, yaitu bisa lapar, haus, letih, sedih bahkan secara fisik juga menglami kematian. Tetapi di dalam diri Yesus juga memiliki sifat kodrat kepenuhan Ilahi yang tidak dimiliki oleh manusia biasa, seperti Yesus tidak pernah berbuat dosa, membuat banyak mujizat yang tidak bisa dilakukan oleh manusia biasa, seperti mencelikkan mata orang buta, membuat orang lumpuh bisa berjalan, membangkitkan orang mati, terlebih lagi kebangkitan-Nya dari kematian selama tiga hari di dalam kubur, dan lain sebagainya. Bahkan juga Yesus akan datang untuk yang kedua kali sebagaimana diri Yesus yang dilihat oleh para murid dalam bentuk manusia ketika Ia naik ke surga akan datang kembali seperti apa yang mereka lihat. Hal ini dapat dilihat pada Kis.1: 11 ketika dua orang malaikat berkata kepada para murid: "Hai orang-orang Galilea, mengapakah kamu berdiri melihat ke langit? Yesus ini yang terangkat ke sorga meninggalkan kamu, akan datang kembali dengan cara yang sama seperti kamu melihat Dia naik ke sorga." Yesus akan datang kembali ke dunia ini dengan ke Mahakuasaan-Nya untuk menghakimi manusia, yang percaya kepada-Nya akan diselamatkan dan yang tidak percaya akan binasa dalam kematian kekal (2 Kor.5: 10).

Dari uraian di atas maka dapat dikatakan bahwa para aliran pluralisme yang tergabung dalam kelompok teolog liberal, telah menutup mata rohaninya untuk melihat akan kebenaran-kebenaran Firman Tuhan yang dituntun oleh pimpinan Roh Kudus yang ada di dalam setiap hati manusia yang percaya kepada Yesus Kristus. Mereka telah terjebak dalam konsep pemikiran yang sempat yang hanya berorientasi dalam satu sisi pandang saja dengan mengabaikan sudut pandang yang lain yang mungkin dapat mengungkapkan pandangan-pandangan baru yang lebih luas dan dapat diterima. Sudah barang tentu hasil pemikiran mereka adalah merupakan pengajaran sesat yang bertentangan dengan terang Firman Tuhan yang telah dikanonisasi dalam Alkitab orang-orang Kristen.

\section{KESIMPULAN}

Kristologi adalah cabang ilmu teologi yang membicarakan tentang posisi Yesus Kristus di dalam agama Kristen. Dalam hal ini Krsitologi adalah merupakan salah satu cabang ilmu teologi yang berbicara dan memaknai tentang hakekat dan keberadaan Yesus. Studi Kristologi sudah ada semasa hidup Yesus sendiri, hal tersebut bisa dilihat dari adanya pertanyaan-pertanyaan yang menyangkut tentang hakekat keberadaan diri-Nya semasa

\footnotetext{
${ }^{31}$ Ibid., 63
} 
hidup-Nya. Perjanjian Baru memberi kesaksian bahwa Allah telah mendatangi manusia dalam kedatangan Yesus Kristus, dan sebaliknya di dalam manusia Yesus orang Nazaret itu kita berjumpa dengan Allah sendiri. Timbulnya dikotomi kedua istilah Christology from Below vs. Christology from Above adalah didasarkan adanya beberapa kaum teolog yang beraliran liberal untuk melakukan penyelidikan tentang Yesus yang berdasarkan sejarah. Tindakan Penyelidikan Yesus Sejarah (The Quest of The Historical Jesus), Kaum liberal telah memperkarsai penyelidikan mengenai Yesus Sejarah dengan mengunggulkan metode kritik Alkitab.

Kristologi yang murni yang sudah ada sebelum adanya penyelidikan Yesus Sejarah adalah merupakan pandangan gereja mula-mula yaitu bahwa Krsitologi dimulai dari atas (from above). Hal ini dimulai dengan pandangan tentang ke-Allah-an dan kemanusiaan Yesus seperti yang terdapat di dalam Injil Yohanes pasal 1. Para teolog beraliran liberal mencetuskan metode kristologi dari bawah (The Christology From Below) yang meletakkan pandangannya dimulai dari manusia Yesus dari Nazaret, kemudian bertanya bagaimana caranya Ia menjadi Allah. Mereka sangat mengutamakan logika berpikir yang tidak dapat menerima sesuatu yang bersifat supranatural yang hanya bisa diterima melalui iman. Keberadaan Allah hanya dapat dibuktikan melalui pernyataan Allah melalui FirmanNya yang telah dikanonisasi dalam Alkitab yang dipercayai dan diimani oleh orang-orang Kristen. Keberadaan Allah hanya dapat diterima melalui iman, meskipun demikian iman itu bukanlah bersifat buta yang tidak memiliki dasar argumentasi sama sekali. Bukti keberadaan Allah telah dinyatakan pada Alkitab sebagai Firman Allah yang telah diilhamkan Allah melalui Roh Kudus yang ditulis oleh para nabi dan Rasul (2 Tim.3: 16).

Keilahian Tuhan Yesus Kristus berdasarkan Injil Yohanes 1:18 yaitu "Bahwa Ia berada di pangkuan Bapa, tidak mengungkapkan perbedaan dalam hakikat atau sifat yang rendah, melainkan menunjukkan hubungan yang akrab dengan Bapa dan keikut-sertaan dalam otoritas Bapa. Dalam hal ini tidak ada perbedaan tingkat kederajatan Allah dalam diri Yesus dengan ke Allahan Bapa di sorga. Para aliran pluralisme yang tergabung dalam kelompok teolog liberal, telah menutup mata rohaninya untuk melihat akan kebenarankebenaran Firman Tuhan yang dituntun oleh pimpinan Roh Kudus. Mereka telah terjebak dalam konsep pemikiran yang sempat yang hanya ber-orientasi dalam satu sisi pandang saja dengan mengabaikan sudut pandang yang lain yang mungkin dapat mengungkapkan pandangan-pandangan baru yang lebih luas dan dapat diterima.

\section{REFERENSI}

W.R.F. Browning, Kamus Alkitab: A Dictionary Of The Bible, Jakarta: BPK Gunung Mulia, 2007

Guthrie, Donald. Teologi Perjanjian Baru 1, Jakarta: BPK Gunung Mulia, 2015

Niftrik, Van, GC, \& BJ. Boland. Dogmatika Masa Kini, Jakarta: BPK Gunung Mulia: 2008

Lumintang, Indra, Stevri. Theologi Abu - Abu Pluralisme Agama, Gandum Mas: 2009 Millard J. Erickson, Christian Theology 
Tong, Stephen. Allah Tritunggal. Surabaya:Momentum, 2013

Ladd, Eldon,George. Teologi Perjanjian Baru Jilid 1. Bandung: Kalam Kudus, 2010

Drane, Jhon. Pemahaman Perjanjian Baru, Jakarta: BPK Gunung Mulia, 2006

Berkhof, Louis. Teologi Sistematika. Surabaya: Momentum Christian Literature, 2007

Hagelberg, Dave. Tafsiran Injil Yohanes Dari Bahasa Yunani. Yogyakarta: ANDI Offset, 2009

Sitohang, H. Samin. Siapakah Nama Sang Pencipta? Bandung: Yayasan Kalam Kudus, 2003

Menzies, W. William \& Stanley M. Horton. Doktrin Alkitab. Malang: Gandum Mas, 2003 https://id.wikipedia.org/wiki/Kristologi

http://sttip.com/modul, isu-isu kristologi kontemporer.pdf 